
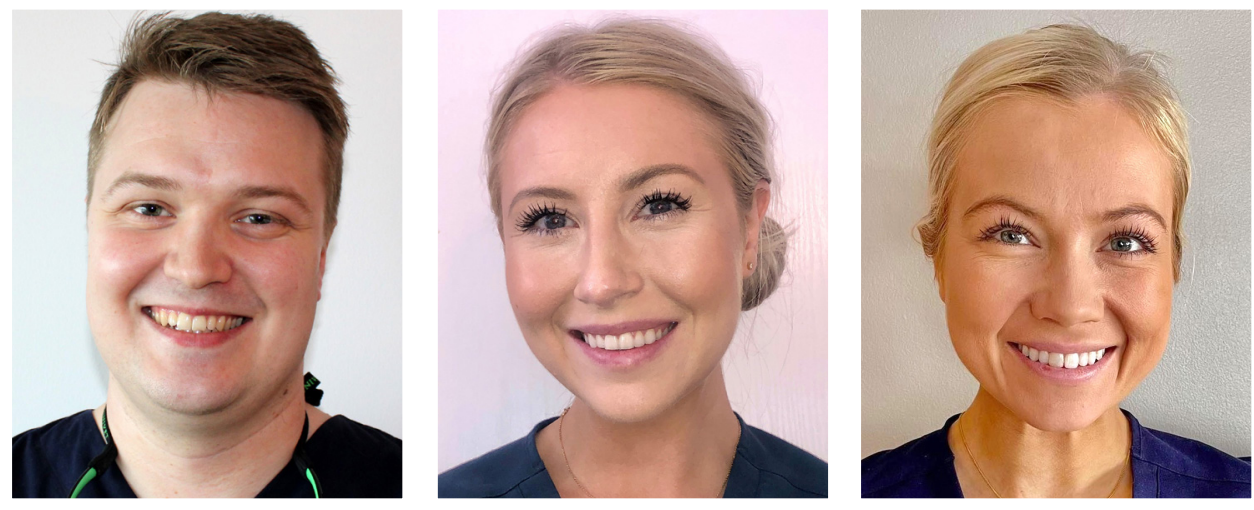

\title{
Glerungseyðandi áhrif rafsígarettuvökva
}

\author{
AEGIR BENEDIKTSSON, CAND. ODONT. \\ ANITTA RUT AXELSDÓTTIR, CAND. ODONT. \\ GRÉTA RUT BJARNADÓTTIR, CAND.ODONT. \\ INGA B ÁRNADÓTTIR, CAND. ODONT. MPH, DOKTOR. ODONT. PRÓFESSOR, TANNLAEKNADEILD HÁSKÓLA \\ ÍSLANDS \\ VILHELM GRÉTAR ÓLAFSSON, CAND. ODONT. MS, LEKTOR, TANNLAEKNADEILD HÁSKÓLA ÍSLANDS
}

NETFÖNG: aegirbenediktsson@gmail.com TANNLAEKNABLAĐIĐ 2021; 39(2): 46-49

doi: 10.33112/tann.39.2.5

\section{ÁGRIP}

Tilgangur: Markmið rannsóknar var að mæla sýrustig ákveðinna rafrettuvökva sem eru á íslenskum markaði og meta áhrif peirra með tilliti til glerungseyðingar.

Efniviður og aðferðir: Notast var við 11 rafsígarettuvökva sem fengust í íslenskum verslunum og sýrustig peirra mælt með pH mæli. Sítrónusafi var notaður sem jákvæð viðmiðunarlausn og kranavatn sem neikvæð viðmiðunarlausn. Notast var við 8 heillegar úrdregnar tennur og pær hlutaðar í tvennt, síðan i fjóra bita og peir vigtaðir. Hverjum krónuhluta var komið fyrir á veltigrind með $2 \mathrm{ml}$ af vökva. Skipt var um lausn á sólarhringsfresti og krónuhlutar vigtaðir eftir 2 vikur.

Niðurstöður: Hefðbundnir rafrettuvökvar voru meira glerungseyðandi heldur en saltrafrettuvökvar, en pyngdartap tannhluta var 0,27-1,64\%. 7 af peim 12 tegundum rafrettuvökva sem rannsakaðir voru höfðu pH gildi sem telst vera undir krítísku sýrustigi tannbeins, $\mathrm{pH} \leq 6.7$ og 6 af pessum vökvum voru með pH gildi undir krítísku pH gildi glerungs, pH $\leq 5.2-5.5$.

Ályktun: Notkun rafsígaretta veldur vægri glerungseyðingu og par með auknu sliti á tönnum. Einnig bykir ljóst að notkun rafsígaretta hefur neikvæð áhrif á flóru munnhols og getur ýtt undir próun tannhaldssjúkdóma.

Lykilorð: glerungseyðing, rafsígarettur, lýðheilsa 


\section{Inngangur}

Ljóst pykir að notkun rafsígaretta hefur farið vaxandi og pá sérstaklega meðal yngra fólks (1, 2). Slys og eitranir vegna vökva og tækja sem eru notuð eru tíð og algengt fréttaefni fjölmiðla. Einnig er ljóst að notkun getur leitt til ýmissa heilsukvilla (3). Rannsóknir sýna að líkt og sígarettureykingar, sem og aðrar tóbaksvörur, hefur notkun rafsígaretta talsverð áhrif á tannhald, en $43 \%$ peirra sem nota pær eru með einhverjar tannhaldsbólgur eða -sýkingar, vegna breytinga sem verða á hefðbundinni bakteríuflóru munnhols. Pessar bólgur valda svo tannhaldssjúkdómum sem lýsa sér með bein- og festutapi $(1,4)$. prátt fyrir að ekki sé búið að framkvæma margar rannsóknir á skaðsemi rafsígretta með tilliti til tanna, virðist nokkuð ljóst að skaðinn er talsverður. Ungir sjúklingar eru að leita sér aðstoðar, par sem farið er að bera á munnpurrki, tannhaldssjúkdómum og aukinni tannátutíðni sem talið er að megi rekja beint til neyslu peirra $(4,5)$. Markmið pessarar rannsóknar er að mæla sýrustig ákveðinna rafrettuvökva sem eru á markaði á Íslandi og meta áhrif peirra með tilliti til glerungseyðingar.

\section{Efniviður og aðferðir}

Notast var við heillega, úrdregna fullorðinsjaxla. Til að byrja með var hver jaxl skorinn við krónurótarmörk og pví næst skorinn í 4 jafna bita með demantsskífu. Premur krónuhlutum var komið fyrir í tilraunaglasi og peir vigtaðir, sem viðmiðunargildi (Mynd 1).

11 vökvar sem fást í rafrettuverslunum á Íslandi voru valdir fyrir rannsóknina (Mynd 2). Sítrónusafi var notaður sem jákvæð viðmiðunarlausn og kranavatn sem neikvæð viðmiðunarlausn (Tafla 1).

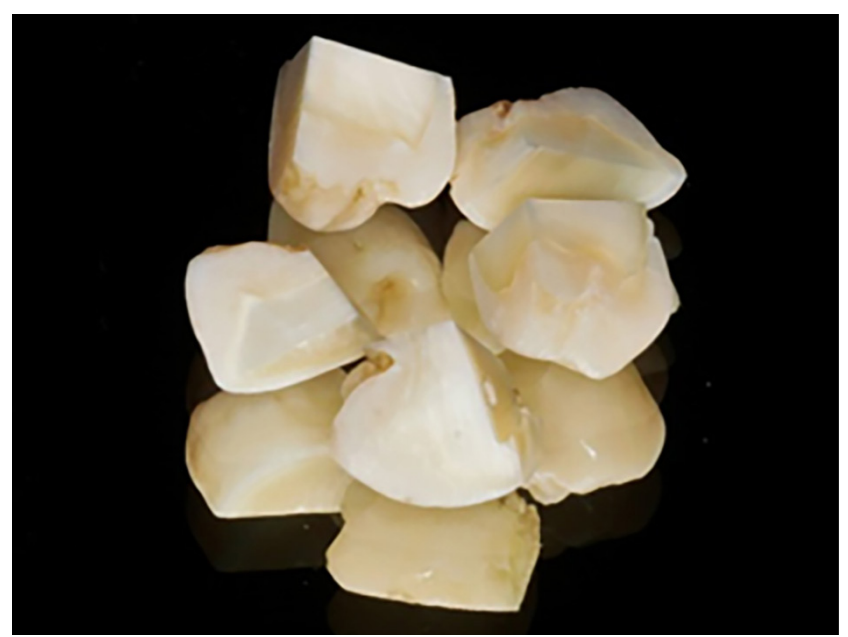

Mynd 1. Krónuhlutar fullorðinsjaxls skorinn i 4 jafna bita.
Sýrustig vökvanna var mælt með sýrustigsmæli sem var kvarðaður fyrir hverja mælingu með stuðpúðalausnum með sýrustigi 4.00, 7.00 og 10.00. Allar mælingar voru framkvæmdar við stofuhita eða $23^{\circ} \mathrm{C}$. Notast var við Oakton pH Testr 30 (Merck KGaA, Darmstadt, Germany)

sýrustigsmæli.

Krónuhlutum var, eftir vigtun, komið fyrir i tilraunaglösum sem hvert innihélt $2 \mathrm{ml}$ af vökva sem huldi tannhlutana alveg. Tilraunaglösum var pví næst komið fyrir á veltigrind og pannig tryggt að vökvinn umhverfis tannhlutanna væri alltaf á hreyfingu og komið í veg fyrir mettun á kalsíum og fosfatjónum í lausninni í nánasta umhverfi krónuhluta. Skipt var um lausn í tilraunaglösum á sólarhringsfresti í tvær vikur. Að pví loknu voru krónuhlutar skolaðir með afjónuðu vatni og hreinsaðir með grisjum par sem lausnirnar voru mjög pykkar og sátu á tannhlutum. Krónuhlutar voru síðan purrkaðir í hitaklefa áður en peir voru vigtaðir aftur líkt og áđur.

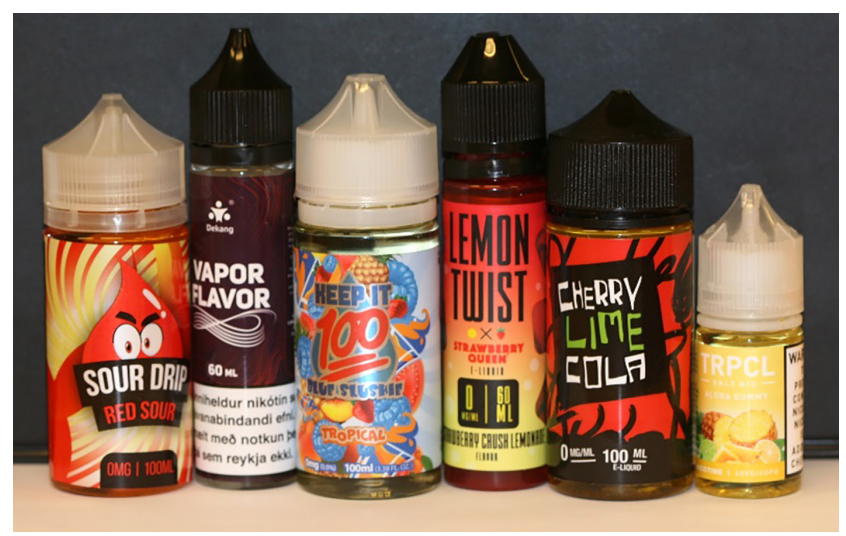

Mynd 2. Nokkrir peirra rafsigarettuvökva sem notaðir voru.

\section{Niðurstöður}

Niðurstöður rannsóknar benda til pess að 7 af peim 12 tegundum rafrettuvökva sem rannsakaðir voru höfðu pH gildi sem telst vera undir krítísku sýrustigi tannbeins, $\mathrm{pH}$ $\leq 6.7$ og 6 af pessum vökvum voru með pH gildi undir krítísku pH gildi glerungs, $\mathrm{pH} \leq 5.2$ - 5.5. Sjá má sýrustig allra rafrettuvökva sem notaðir voru við rannsóknina í Töflu 1. Niðurstöður benda til pess að vökvarnir og notkun peirra geti leitt til glerungseyðingar á tannvef.

Tafla 2 staðfestir petta einnig, en í henni má sjá pyngd tannbúta eftir að peir höfðu legið í rafrettuvökvum i 14 daga. Sjá má að hlutfall tapaðs tannvefs er milli 0,27 - 1,64\%, ef frá eru taldar viðmiðunarlausnir. pær upplýsingar benda 
til pess að pessir vökvar séu með væg glerungseyðandi áhrif. pað sem vekur athygli er að peir vökvar sem flokkast undir saltvökva eru að valda markvert minna hlutfallslegu pyngdartapi, heldur en peir vökvar sem eru hefðbundnir. Álykta má að saltafleiður sem eru til staðar í peim lausnum vinni gegn eyðingunni.

I Töflu 3 má finna nöfn á öllum peim rafrettuvökvum sem notaðir voru við rannsóknina, skráð innihaldsefni og hvort peir eru sagðir innihalda nikotín eđa ekki. Innihaldslýsingar vökvanna voru flestar ónákvæmar og erfitt að lesa úr peim. Að finna út hvort vökvar innihalda nikótín eða ekki var einnig mjög flókið og í mörgum tilfellum villandi. Innihaldslýsing allra vökva voru hins vegar svipaðar og innihalda peir glycerin, glycol og einhvers konar bragðefni.

Tafla 1. Sýrustig efna í rannsókninni.

\begin{tabular}{|l|c|}
\hline Bragdtegund & pH \\
\hline Bragðlaust & 9.06 \\
\hline Lemon Twist & 7.11 \\
\hline Blue Slushie Tropical & 5.11 \\
\hline Red Sour & 6.82 \\
\hline Cherry Lime Cola & 7 \\
\hline Saltvökvi - TRPCL Aloha & 3.97 \\
\hline Sítrónusafi & 2.42 \\
\hline Vatn & 7.5 \\
\hline Nasty salt - hippie trail (1) & 4.44 \\
\hline Candy king peach rings (2) & 4.75 \\
\hline Tropic king berry breeze(3) & 5.02 \\
\hline
\end{tabular}

Tafla 2. Hlutfallslegt pyndartap tannbúta eftir 2 vikur í vökva.

\begin{tabular}{|c|c|c|c|}
\hline Númer vökva & Pyngd fyrir & Pyngd eftir & Pyngdartap $\%$ \\
\hline $\mathbf{1}$ & 0.3907 & 0.3859 & $1.23 \%$ \\
\hline $\mathbf{2}$ & 0.4659 & 0.4591 & $1.46 \%$ \\
\hline $\mathbf{3}$ & 0.3021 & 0.2992 & $0.96 \%$ \\
\hline $\mathbf{4}$ & 0.4333 & 0.4262 & $1.64 \%$ \\
\hline $\mathbf{5}$ & 0.4236 & 0.4182 & $1.23 \%$ \\
\hline $\mathbf{6}$ & 0.4245 & 0.4232 & $0.31 \%$ \\
\hline $\mathbf{7}$ & 0.3502 & 0.0477 & $86.38 \%$ \\
\hline $\mathbf{8}$ & 0.3477 & 0.3477 & $0 \%$ \\
\hline $\mathbf{9}$ & 0.5123 & 0.5087 & $0.70 \%$ \\
\hline $\mathbf{1 0}$ & 0.4435 & 0.4423 & $0,27 \%$ \\
\hline $\mathbf{1 1}$ & 0.4532 & 0.4501 & $0,68 \%$ \\
\hline
\end{tabular}

Tafla 3: Innihaldslýsingar vökva sem voru skoðaðir.

\begin{tabular}{|l|l|l|c|}
\hline Heiti & Gerð vökva & Innihaldsefni & Nikotín \\
\hline 1. Bragðlaust & Hefðbundinn & $\begin{array}{l}\text { Propyloene glycogen, } \\
\text { glycerin og bragðefni }\end{array}$ & Já \\
\hline $\begin{array}{l}\text { 2. Lemon } \\
\text { twist }\end{array}$ & Hefðbundinn & $\begin{array}{l}\text { Vegetable glycerin, USP } \\
\text { Kosher propylene glycol, } \\
\text { natural \& artificial } \\
\text { bragðefni }\end{array}$ & Nei \\
\hline $\begin{array}{l}\text { 3. Blue } \\
\text { Slushie } \\
\text { Tropical }\end{array}$ & Hefðbundinn & $\begin{array}{l}\text { Propyloene glycol, } \\
\text { glycerin og natural og } \\
\text { artificial bragðefni }\end{array}$ & Já \\
\hline $\begin{array}{l}\text { 4. Red Sour } \\
\text { Hefðbundinn }\end{array}$ & $\begin{array}{l}\text { Propyloene glycol, } \\
\text { glycerin og bragðefni }\end{array}$ & Já \\
\hline $\begin{array}{l}\text { 5. Cherry lime } \\
\text { cola }\end{array}$ & Hefðbundinn & $\begin{array}{l}\text { Vegetable glycerin, } \\
\text { propylene glycol, natural } \\
\text { \& artificial bragðefni }\end{array}$ & Nei \\
\hline $\begin{array}{l}\text { 6. TRPCL } \\
\text { Aloha gummy }\end{array}$ & Saltvökvi & $\begin{array}{l}\text { Vegetable glycerin, } \\
\text { propylene glycol, natural } \\
\text { \& artificial bragððefni }\end{array}$ & Já \\
\hline $\begin{array}{l}\text { 8. nasty salt } \\
\text { - hippie trail } \\
\text { lemmon lime }\end{array}$ & Saltvökvi & $\begin{array}{l}\text { Vegetable glycerin, } \\
\text { propylene glycol, natural } \\
\text { \& artificial bragðefni }\end{array}$ & Já \\
\hline $\begin{array}{l}\text { 9. Candy king } \\
\text { peach rings } \\
\text { king berry } \\
\text { breeze }\end{array}$ & Saltvökvi & $\begin{array}{l}\text { Vegetable glycerin, } \\
\text { propylene glycol, natural } \\
\text { \& artificial bragðefni }\end{array}$ & Já \\
\hline $\begin{array}{l}\text { Vegetable glycerin, } \\
\text { propylene glycol, natural } \\
\text { \& artificial bragðefni }\end{array}$ & Já \\
\hline
\end{tabular}

\section{Ályktanir}

Niðurstöður rannsóknar benda til bess að rafrettuvökvar geti valdið glerungseyðingu. Vökvarnir eru missúrir og eru saltvökvar með markvert lægra pH gildi heldur en peir hefðbundnu. Söltin virðast draga úr peirri eyðingu sem á sér stað hjá vökvum sem ekki innihalda pessi sölt.

Miðað við pær niðurstöður sem fengust í pessari rannsókn má leiða líkur af pví að notkun rafretta geti valdið heilsufars vandamálum í munnholi. pað sem einnig hefur komið í ljós er að vökvarnir geta í sumum tilfellum verið pannig samsettir að peir valda glerungseyðingu sem getur haft í för með sér óhóflegt slit á tönnum. Í flestum verslunum sem bjóða upp á pessa vöru er rafrettuvökvum skipt í tvo flokka, venjulega vökva og saltvökva. Рað sem vakti athygli er að saltvökvar virðast vera almennt súrari en peir hefðbundnu. Bragðlausi vökvinn var hins vegar nánast basískur.

Pegar hlutfallslegt pyngdartap tannvefs var metið, kom í ljós að ekki allir af peim vökvum sem voru skoðaðir valda glerungseyðingu. Pað er hins vegar erfitt að sjá fyrir hvort peir eru glerungseyðandi eða ekki. pað sem vakti 
einnig áhuga höfunda er hversu illa merkt allt er í pessum ¡ðnaði. Sem dæmi má nefna að sumir vökvar sem voru voru nikótínlausir, en seldir sem nikótínvökvar. Petta getur verið mjög ruglandi fyrir neytendur. Einnig pykir höfundum líklegt að petta eigi við aðrar nikótínvörur sem njóta vaxandi vinsælda á undanförnum mánuðum.

\section{Umræður}

Aðeins virðist hafa dregið úr notkun rafretta, en á móti virðist neysla annarra nikotínforma hafa aukist og pá sérstaklega nikotínpúđar, sem eru nýjasta viðbótin á nikotínmarkaði. Líkt og með rafrettur er margt ópekkt varðandi áhrif peirra á heilsu neytanda. prátt fyrir að vera engan vegin í sama glerungseyðandi flokki eins og súrir gosdrykkir, getur notkun rafretta verið áhrifapáttur sem ýtir enn frekar undir glerungseyðingu sem hefur aukist með nútíma lifnaðarháttum.

\section{Pakkir}

Lýðheilsusjóði er pakkað fyrir að styrk og Líf- og heilbrigðisvísindaráđstefnu Háskóla Íslands fyrir að gefa okkur tækifæri á að kynna niðurstöður rannsóknarinnar. Svend Richter fyrir leiðbeiningar og yfirlestur við skrif greinarinnar.

\section{Heimildir}

1. Pushalkar S, Paul B, Li Q, Yang J, Vasconcelos R, Makwana S, et al. Electronic Cigarette Aerosol Modulates the Oral Microbiome and Increases Risk of Infections. iScience 2020; 23(3): 1-14. Mars 2020.

2. Silija Katrín Davíðsdóttir og Steinunn Póra Ađalsteinsdóttir. Tóbaks- og nikótínnotkun nemenda Hí og almenn pekking peirra á afleiðingum neyslunnar á munn- og tannheilsu. BS ritgerð, Tannlæknadeild, Háskóli İ́lands, 2020.

3. Hua, M og Talbot, P. Potential health effects of electronic cigarettes: A systematic review of case reports. Prev. Med. Rep. 2016; 4: 169-178.

4. Precher, M. Need another reason not to vape? Your oral health is at risk. American Heart Association News. https://www.heart.org/en/news/2020/08/26/need-anotherreason-not-to-vape-your-oral-health-is-at-risk (Ágúst 2020).

5. Precher, M. Need another reason not to vape? Your oral health is at risk. American Heart Association News. https://www.heart.org/en/news/2020/08/26/need-anotherreason-not-to-vape-your-oral-health-is-at-risk (Ágúst 2020).

\title{
English Summary
}

\section{Erosive Capacity of Electronic Cigarettes Liquids}

\author{
AEGIR BENEDIKTSSON, DDS \\ ANITTA RUT AXELSDÓTTIR, DDS \\ GRÉTA RUT BJARNADÓTTIR, DDS \\ INGA B ÁRNADÓTTIR, DDS. MPH, PH.D., PROFESSOR, UNIVERSITY OF ICELAND, FACULTY OF ODONTOLOGY, \\ REYKJAVIK, ICELAND \\ VILHELM GRÉTAR ÓLAFSSON DDS. MSC, ASSISTANT PROFESSOR, UNIVERSITY OF ICELAND, FACULTY OF \\ ODONTOLOGY, REYKJAVIK, ICELAND
}

ICELANDIC DENT J 2021; 39(2): 46-49

doi: 10.33112/tann.39.2.5

Introduction: The aim of this study was to measure $\mathrm{pH}$ values of electronic cigarettes liquids

and to evaluate their erosive capacity via weight loss percentage.

Materials and methods: A pH analysis was performed for 11 different available products on the Icelandic market. Lemon juice and tap water were used as positive and negative control. Crowns of 8 molars were sectioned with a low speed saw through the middle and thereafter each specimen was weighed. The specimens were submerged in $2 \mathrm{~mL}$ of each test product

which was renewed every 24 hours for two weeks. After two weeks the specimens were rinsed, dried, and weighed. Weight loss percentage was used to evaluate the erosive capacity of each product.

Results: The erosive capacity of the products was between $0.27-1.64 \% .7$ of the products tested had a pH value below critical pH of dentin and 6 of them below critical pH of enamel. Every product tested had

Conclusion: Most products tested had some erosive capacity. In addition, we know the effects vaping can have on general health and the progression of periodontal diseases so their usage cannot be recommended.

Keywords: Dental erosion, vape, public health

Correspondence: AEgir Benediktsson, e-mail: aegirbenediktsson@gmail.com 